\title{
Influence of natural and anthropogenic emissions on aerosol optical properties over a tropical urban site - a study using sky radiometer and satellite data
}

\author{
K.V.S.Badarinath ${ }^{1}$, D.Goto ${ }^{2}$, Shailesh Kumar Kharol ${ }^{1}$, D.V.Mahalakshmi ${ }^{1}$, Anu Rani \\ Sharma $^{1}$, T.Nakajima ${ }^{2}$, M.Hashimoto ${ }^{2}$ and T.Takemura ${ }^{3}$
}

\author{
${ }^{1}$ Atmospheric Science Section, Atmospheric Sciences and Oceanography Group, National \\ Remote Sensing Centre, Dept. of Space-Govt. of India, alanagar, \\ Hyderabad - 500 625, India. Email: badrinath kvs@nrsc.gov.in \\ ${ }^{2}$ Atmosphere Ocean Research Institute, University of Tokyo, Kashiwa, Chiba, Japan. \\ ${ }^{3}$ Research Institute for Applied Mechanics, Kyusyu University, Kasuga, Fukuoka,Japan.
}

17 Atmospheric aerosols are important aspects of climate research due to their impact on 18 radiative forcing. In the present study, the aerosol optical depth (AOD), the Ångström 19 exponent $(\alpha)$ and the single scattering albedo (SSA) over the urban region of Hyderabad,

20 India, were examined using Sun/Sky radiometer measurements during January December, 2008. AOD showed higher values on certain Julian days coinciding with the occurrence of wintertime dust storm events in the Gulf Region and biomass burning due to forest fires over Indian Region. The AOD values during wintertime dust event are about $\sim 55 \%$ higher than those on normal days. The SSAs show positive and negative trends in $\alpha\left(\mathrm{R}^{2}=0.71\right)$ and black carbon $(\mathrm{BC})$ aerosols $\left(\mathrm{R}^{2}=0.44\right)$, respectively. The aerosol size distribution shows a bimodal pattern with fine $(\sim 0.15 \mathrm{~m})$ and coarse $(\sim>7$ m) mode during January -December, 2008. The MODIS AOD showed positive correlation with sky radiometer-derived AOD values $\left(\mathrm{R}^{2}=0.68\right)$.

Keywords: AOD, SSA, forest fires, Dust storms, black carbon 


\section{Introduction}

2 In the current assessment and prediction of global climate change, atmospheric aerosol

3 concentrations and their optical properties are one of the largest sources of uncertainty

4 (Hansen et al., 2000). Aerosol interactions with solar radiations results in both direct

5 radiative forcing and indirect effects on clouds involving droplet properties, cloud

6 dynamics and lifetime. Direct radiative forcing from aerosols is primarily a function of

7 aerosol concentration in the total atmospheric column (aerosol optical depth), particle

8 size distributions, and aerosol absorption properties (Eck et al., 2005). An accurate

9 knowledge of the spatial and temporal extent of aerosol concentrations and properties is

10 necessary for understanding the role of aerosols on climate (Hatzianastassiou et al.,

11 2005). In this regard, several extensive observations on the optical properties of

12 atmospheric aerosols were made using Sun/Sky radiometer at global scale (Liu et al.,

13 2008; Cazorla et al., 2008; Kim et al., 2007; Arai and Liang, 2007; Cheng et al., 2006;

14 Pandithurai et al., 2007). The best strategy for characterizing aerosols is to integrate

15 measurements from different satellite sensors and ground-based measurements and

16 models. Aerosols produced at one location can even reach far-off regions owing to

17 prevailing transport mechanisms. Anthropogenic activities such as biomass burning,

18 industrial emissions and vehicular combustion can influence the characteristics and

19 distribution of aerosols. Several attempts are being made all over the world to

20 characterize aerosols on regional basis and to form realistic and comprehensive models of

21 aerosol parameters. Several experiments to characterize atmospheric aerosols were

22 conducted over mid-latitudes and/or oceanic environments (Nair et al., 2004a;

23 Ramanathan et al., 2001), while only few studies have been reported from tropical

24 continental sites where spatial inhomogeneties are more pronounced.

Mineral dust is considered as one of the major contributors to the aerosol loading in the troposphere influencing the seasonal variability of the aerosol optical properties and the local radiative forcing (Durant et al., 2009; Liu et al., 2003). Dust storms have considerable impacts on climate variability, nutrient dynamics and biogeochemical cycles

30 of oceans, soil characteristics, and ambient air quality. Satellite and surface observations

31 have shown that the global sources of the atmospheric dusts are the arid and semi-arid

32 desert regions contributing to the long-range transport of dust particles lifted by strong

33 surface winds $\left(>5 \mathrm{~m} \mathrm{~s}^{-1}\right)$ (Prospero et al., 2002; Washington et al., 2003). 
1 The present study describes the columnar aerosol properties over the urban region of

2 Hyderabad, India, using ground-based sun/sky radiometer measurements, satellite data

3 and on global three-dimensional aerosol transport model.

5 2. Study Area

6 The study area of Hyderabad, India, is located between $17^{\circ} 10^{\prime}$ and $17^{\circ} 50^{\prime} \mathrm{N}$ latitude and

$778^{\circ} 10^{\prime}$ and $78^{\circ} 50^{\prime} \mathrm{E}$ longitude. Hyderabad is the fifth largest city of India, highly 8 urbanized with population of 5,751,780 inhabitants (census 2001). The city is influenced

9 not only by vehicular pollutants, but also by industrial as well as biomass-burning 10 emissions. The climate of the region is semi-arid with a total rainfall of $\sim 700 \mathrm{~mm}$ 11 occurring mostly during the monsoon season in the June-October period. The climatology 12 of the area experiences four dominant seasons each year, winter (December-February), 13 pre-monsoon (March-May), monsoon (June-September), and post - monsoon (October14 November). The measurements reported in this work were carried out under clear-sky 15 conditions in the premises of the National Remote Sensing Centre (NRSC) campus 16 located at Balanagar $\left(17^{\circ} 28^{\prime} \mathrm{N}\right.$ and $\left.78^{\circ} 26^{\prime} \mathrm{E}\right)$ well within the urban center of 17 Hyderabad.

\section{Datasets and Methodology}

20 Extensive aerosol observations were carried out at the National Remote Sensing Centre, 21 Hyderabad, India, using a Prede sun/sky radiometer (POM-01L, Prede Incorporated, 22 Japan) during January - December, 2008. This instrument is widely used in the SKYNET 23 aerosol radiation network (http://atmos.cr.chiba-u.ac.jp/aerosol/skynet) for sun/sky 24 observations, which can be used to retrieve aerosol optical depth and Ångström exponent. 25 This instrument makes measurements of both direct and diffuse sky radiances at pre26 defined scattering angles at regular intervals. The sun/sky radiometer was operated from 27 January - December, 2008 on clear-sky days at 10-min intervals. The sun/sky radiance 28 data were analysed with the radiative transfer model SkyRad Pack version 4.2 (Nakajima 29 et al., 1996; http://www.ccsr.u-tokyo.ac.jp/ clastr/) to retrieve aerosol optical depth 30 (AOD), single scattering albedo (SSA), Ångström exponent $(\alpha)$ and volume size 31 distribution. AOD is calculated on the basis of the Beer-Lambert-Bouger law with 32 correction for Rayleigh scattering, the change of Sun-Earth distance, and ozone optical 33 depth by considering the average columnar Ozone value of $300 \mathrm{DU}$. The sky radiometer 34 was operated in disc scan mode to estimate the solid view angles at different wavelengths 35 as part of a calibration procedure recommended by the manufacturer. Detailed calibration 
1 and data reduction procedures for this instrument are described elsewhere (Nakajima et

2 al., 1996; Pandithurai et al., 2007).

4 The Ångström exponent was derived from the spectral dependence of AOD $\left(\tau_{a}\right)$ 5 observed at 400, 500, 675, 870 and 1020-nm wavelengths using Ångström's formula 6 (Ångström, 1964):

10 where $\tau_{a}$ is the estimated AOD at the wavelength , is the Ångström's turbidity 11 coefficient, which equals AOD at $=1 \mathrm{~m}$, and is the Ångström exponent.

13 Continuous and near-real-time measurements of black carbon (BC) aerosol mass 14 concentration were carried out using an aethalometer; model AE-21 of Magee Scientific, 15 USA (Borak et al., 2003). The instrument takes ambient air from an altitude of $3 \mathrm{~m}$ above 16 the ground using its inlet tube and pump. The $\mathrm{BC}$ mass concentration is estimated by 17 measuring the change in the transmittance of a quartz filter tape, on to which the particles 18 impinge. The instrument was operated at a time base of $5 \mathrm{~min}$, round the clock with a

19 flow rate of 2.6 LPM. The instrument has been factory-calibrated and errors in the 20 measurements are $02 \%$.

22 In addition, MODIS active fire locations products from web fire maps 23 (http://maps.geog.umd.edu/activefire html/) were used for the study period. MODIS Fire 24 detection is performed using a contextual algorithm (Giglio et al., 2003) that exploits the 25 strong emission of mid-infrared radiation from fires. The algorithm uses brightness 26 temperatures derived from the MODIS 4- and 11- $\mu \mathrm{m}$ channels. The description of 27 MODIS fire products generation is given elsewhere (Giglio et al., 2003). NOAA 28 HYSPLIT model runs and meteorological fields from NCEP reanalysis data were used to 29 study the air mass trajectories over the region (Draxler and Rolph, 2003).

\section{Results and Discussion}

32 Figure $-1(\mathrm{a}-\mathrm{c})$ shows the variation of daily mean AOD, SSA at $500 \mathrm{~nm}$ and $\alpha$ with

33 standard deviation of the daily averaged value derived from sky radiometer during 34 January - December, 2008. There are some gaps in the time series due to prevailing 
1 atmospheric conditions, which did not provide enough clear-sky days for measurements.

2 The AOD values showed an increase on certain Julian days (i.e., 33, 49-52, 56 and 68), as

3 shown in Figure - 1a. The high AOD values during Julian days 49-52, 56 are associated

4 with biomass-burning activity over the Indian region as shown in MODIS fire images of

5 Figure - 6. The AOD during wintertime dust event (Julian day 33) was about 50-55\%

6 higher than the optical depth obtained on normal days. SSA is a useful quantitative

7 parameter for estimating radiative properties of aerosols (Lewis et al., 2008). The SSA

8 values at $500 \mathrm{~nm}$ varied between $0.9-1.0$ over the region during the study period as shown

9 in Figure - 2b. The SSA values derived from PREDE skyradiometer at different

10 wavelengths are summarized in Figure - 3. The day-to-day variations observed in SSA

11 were related to meteorological conditions, variations in air mass trajectory, relative

12 humidity, temperature inversions, biomass burning episodes and dust particles driven by

13 high winds over the region. The lower values of SSA on certain days are mainly due to

14 presence of absorbing aerosols over the region. The gradual decrease in $\alpha$ values were

15 observed on certain days during February - March due to the dominance of coarse mode

16 particles associated with wintertime dust storm events over the region (Figure $-1 \mathrm{f}$ ). $\alpha$ is a

17 good indicator of aerosol-size distribution and its variation. The magnitude of $\alpha$ is

18 determined by the fraction ratio of fine and coarse modes. The $\alpha$ values are small $(\sim<$

19 1.0) during the dominance of course mode particles (Eck et al., 2005).

21 Figure $-4(\mathrm{a}-\mathrm{b})$ shows the scatter plots of SSA at a wavelength of $500 \mathrm{~nm}\left(\mathrm{SSA}_{500}\right)$ vs $\alpha$ 22 and $\mathrm{BC}$ aerosol mass concentration over the study area. $\alpha$ showed linear relation $\left(\mathrm{R}^{2}=\right.$ 23 0.71) with $\mathrm{SSA}_{500}$ suggesting that higher $\mathrm{SSA}_{500}$ values are associated with fine-mode 24 particles. $\mathrm{SSA}_{500}$ showed negative correlation with $\mathrm{BC}$ aerosol mass concentration $\left(\mathrm{R}^{2}=\right.$ 25 0.44) (Figure - 4b) suggesting that low SSA $_{500}$ values were due to absorbing aerosols 26 over the region. The instantaneous BC values were observed to be higher than $40 \mathrm{~g} / \mathrm{m}^{3}$

27 during the biomass-burning period; BC values less than $40 \mathrm{~g} / \mathrm{m}^{3}$ are considered in Figure $28-4$ b. Earlier studies based on aircraft measurements over the study site suggested an 29 elevated layer of BC aerosols up to $2 \mathrm{~km}$ height during winter period (Krishna Moorthy et 30 al., 2004). In urban regions, there is a possibility of elevated aerosol layers occurring due 31 to heat island formation and related convective activity.

33 Terra and Aqua MODIS (Moderate Resolution Imaging Spectroradiometer) true color 34 composite images were analyzed to study the intense dust aerosol loading over the 
1 Arabian Sea on $2^{\text {nd }}$ February and $8^{\text {th }}$ March, 2008 (Figures - 5 (a \& b)). Wintertime dust-

2 storms events over Asian region are the main source of dust aerosol loading in to the

3 atmosphere and these dust aerosols are transported at long distances under favorable wind

4 conditions (Kim et al., 2008). It is evident from Figure - 5 that the entire Gulf region and

5 Arabian Sea were under influence of dust aerosols on $2^{\text {nd }}$ February and $8^{\text {th }}$ March, 2008.

6 These dust aerosols were transported downwind and affected the atmospheric aerosol

7 properties over the measurement site as shown in Figure - 1. Five-day back trajectories

8 from NOAA HYSPLIT model were analyzed to study the role of long-range transport

9 over the urban region of Hyderabad during dust storm and biomass-burning events over

10 the region. Figure -6 shows the 5-day backward trajectories for $2^{\text {nd }}$ February (Julian day

11 33) and $8^{\text {th }}$ March, 2008 (Julian day 68), respectively. The back trajectories suggest that

12 air mass from north-western region having dust storms and biomass burning due to forest

13 fires was advected over the study site resulting in increased columnar aerosol mass

14 concentration. The increase in columnar loading of absorbing aerosols resulted in

15 decrease in SSA values shown in Figure - 2. Earlier studies over the region reported

16 long-range transport of aerosols from biomass burning and dust storm over the region

17 (Kharol et al., 2006; Badarinath et al., 2007a \& b).

19 Figure -8 and 9 shows the sky-radiometer-derived monthly and seasonal variations in 20 aerosol volume-size distribution during 2008. The aerosol volume-size distribution has

21 bimodal structure with one peak at about $0.15 \mathrm{~m}$ showing a maximum value in February 22 due to anthropogenic emissions and biomass burning due to forest fires. The second peak 23 with a radius of about $7 \mathrm{~m}$ in winter is due to coarse-mode particles over the region due 24 to dust events as shown in Figure - 5. The coarse-mode aerosol volume-size distribution 25 derived from inversion of PREDE skyradiometer are reported to differ from CIMEL 26 skyradiometer (Che et al., 2008); the possible discrepancies due to the SKYRAD pack are 27 under further investigated.

29 Sky radiometer $\mathrm{AOD}$ at $500-\mathrm{nm}$ wavelength is converted to $550 \mathrm{~nm}\left(\mathrm{AOD}_{550}\right)$ using 30 Ångström's formula for comparing it with Terra MODIS derived AOD at $550 \mathrm{~nm}$. 31 (Ångström, 1964). Figure - 10 shows the scatter plot of Terra MODIS AOD D $_{50}$ and sky 32 radiometer-derived $\mathrm{AOD}_{550}$ suggesting a correlation $\left(\mathrm{R}^{2}=0.68\right)$. and the deviation has 33 been attributed to spatial resolution of MODIS sensor besides other governing factors.

34 Similar observation over Hong Kong $\left(\mathrm{R}^{2}=0.625\right)$ was reported in the literature (Cheng et 35 al., 2006). 


\section{Conclusions}

3 Aerosol optical depth (AOD), Ångström exponent ( $\alpha$ ), single scattering albedo (SSA) and volume-size distributions were investigated using satellite data and sky radiometer data at the urban region of Hyderabad, India, during January-December, 2008. The results of study suggested that -

\section{Acknowledgement}

The authors thank Director of NRSC and Deputy Director (RS\&GIS-AA) for necessary help at various stages of this work and ISRO-GBP for funding the project. The authors express their sincere thanks to Dr. Diehl and AeroCom project for providing emission data sets. The reanalysis data from NCEP/OAR/ESRL PSD, Boulder, Colorado, USA, and the HadISST data from Hadley Centre, UK Met Office are gratefully acknowledged. The model simulations were performed using the National Institute for Environmental Studies, Japan, supercomputer system (NEC SX-8R/128M16). A part of the authors were supported by projects from JAXA/EarthCARE, MEXT/VL for Climate System Diagnostics, MOE/Global Environment Research Fund B-083, NIES/GOSAT, and JST/CREST. 


\section{References}

Ångström, A., 1964. The parameters of atmospheric turbidity. Tellus, 16, 64-75.

Arai, K. and Liang, X., 2007. Characterization of aerosols in Saga city areas in Japan with direct and diffuse solar irradiance and aureole observations. Advances in Space Research, 39(1), 23-27.

Badarinath, K.V.S., Kharol, S. K., Kaskaoutis, D.G. and Kambezidis, H.D., 2007a. Influence of atmospheric aerosols on solar spectral irradiance in an urban area. J. Atmos. Sol. Terr. Phys., 69, 589-599.

Badarinath, K.V.S., Kharol, S. K., Kaskaoutis, D.G. and Kambezidis, H.D., 2007b. Dust storm over Indian region and its impact on the ground reaching solar radiation - A case study using multi-satellite data and ground measurements. Science of the Total Environment, 384, 316-332.

Borak, J., Sirianni, G., Cohen, H.J., Chemerynski, S. and Wheeler, R., 2003. Comparison of NIOSH 5040 method versus aethalometer to monitor diesel particulate in school buses and at work sites. AIHA J. 64, 260-268 March/April.

Cazorla, A., Olmo, F.J. and Alados-Arboledas, L., 2008. Using a Sky Image for aerosol characterization. Atmospheric Environment, 42(11),2739-2745.

Che, H, Shi, G., Uchiyama, A., Yamazaki, A., Chen, H., Goloub, P., and Zhang, X., 2008. Intercomparison between aerosol optical properties by a PREDE skyradiometer and CIMEL sunphotometer over Beijing, China, Atmos. Chem. Phys., 8, 3199-3214.

Cheng, A. Y. S., Chan, M. H. and Yang, X., 2006. Study of aerosol optical thickness in Hong Kong, validation, results and dependence on meteorological parameters. Atmospheric Environment, 40, 4469-4477.

Draxler, R.R. and Rolph, G.D., 2003. HYSPLIT (Hybrid Single-Particle Lagrangian Integrated Trajectory) model, http://www.arl.noaa.gov/ready/hysplit4.html, NOAA Air Resour. Lab., Silver Spring, MD.

Durant, A. J., Harrison, S. P., Watson, I. M. and Balkanski, Y., 2009. Sensitivity of direct radiative forcing by mineral dust to particle characteristics. Progress in Physical Geography, 33 (1), 80-102.

Eck, T. F., Holben, B. N., Dubovik, O., Smirnov, A., Goloub, P., Chen, H.B., Chatenet, B., Gomes, L., Zhang, X.-Y., Tsay, S.-C., Ji, Q., Giles, D. and Slutsker, I., 2005. Columnar aerosol optical properties at AERONET sites in central eastern Asia and aerosol transport to the tropical mid-Pacific. Journal of Geophysical Research, 110, D06202, doi:10.1029/2004JD005274, 2005.

Giglio, L., Kendall, J. D. and Mack, R., 2003. A multi-year active fire data set for the tropics derived from the TRMM VIRS, Int. J. Rem. Sens., 24, 4505-4525.

Hansen, J., Sato, M., Ruedy, R., Lacis, A. and Oinas, V., 2000. Global warming in the twenty-first century: An alternative scenario, Proc. Natl. Acad. Sci. U. S. A., 97, 98759880 . 
Hatzianastassiou, N., Matsoukas, C., Fotiadi, A., Pavlakis, K.G., Drakakis, E., Hatzidimitriou, D., and Vardavas., I., 2005. Global distribution of Earth's surface shortwave radiation budget, Atmosphere Chemistry Physics, 5, 2847-2867.

Kharol, S. K. and Badarinath, K. V. S., 2006. Impact of biomass burning on aerosol properties over tropical urban region of Hyderabad, India, Geophysical Research Letters, 33, L20801, doi: 10.1029/2006GL026759.

Kim, S. W., Yoon, S.C., Kim, J. and Kim, S.Y., 2007. Seasonal and monthly variations of columnar aerosol optical properties over east Asia determined from multi-year MODIS, LIDAR, and AERONET Sun/sky radiometer measurements. Atmospheric Environment, 41(8), 1634-1651.

Kim, S.W., Yoon, S.C. and Kim, J., 2008. Columnar Asian dust particle properties observed by sun/sky radiometers from 2000 to 2006 in Korea. Atmospheric Environment, $42,492-504$.

Krishna Moorthy, K., Babu, S. S., Sunilkumar, S. V., Gupta, P. K. and Gera, B. S., 2004. Altitude profiles of aerosol BC, derived from aircraft measurements over an inland urban location in India. Geophysical Research Letters, 31, L22103, doi:10.1029/2004GL021336.

Liu, X., Wang, J. and Christopher, S. A., 2003. Shortwave direct radiative forcing of Saharan dust aerosols over the Atlantic Ocean. Int. J. Remote Sensing, 24 (24), 51475160.

Lewis, K., Arnott, W. P., Moosmüller, H. and Wold, C. E., 2008. Strong spectral variation of biomass smoke light absorption and single scattering albedo observed with a novel dual-wavelength photoacoustic instrument, J. Geophys. Res., 113, D16203, doi: 10.1029/2007JD009699.

Liu, J., Zheng, Y., Li, Z. and Wu, R., 2008. Ground-based remote sensing of aerosol optical properties in one city in Northwest China. Atmospheric Research, 89(1-2), 194205.

Nair, P. R., Parameswaran, K., Sunil Kumar, S.V. and Rajan, R., 2004a. Continental influence on the spatial distribution of particulate loading over the Indian Ocean during winter season. Journal of Atmospheric and Solar Terrestrial Physics, 66, 27-38.

Nakajima, T., Tonna, G., Rao, R., Boi, P., Kaufman, Y. and Holben, B. N., 1996. Use of sky brightness measurements from ground for remote sensing of particulate polydispersions. Appl. Opt., 35, 2672-2686.

Pandithurai, G., Pinker, R. T., Devara, P.C.S., Takamura, T. and Dani, K.K., 2007. Seasonal asymmetry in diurnal variation of aerosol optical characteristics over Pune, western India. Journal of Geophysical Research, 112, D08208, doi:10.1029/2006JD007803, 2007.

Prospero, J. M., Ginoux, P., Torres, O., Nicholson, S. E. and Gill, T. E. 2002. Environmental characterization of global sources of atmospheric soil dust identified with the Nimbus 7 Total ozone Mapping Spectrometer (TOMS) absorbing aerosol product, Rev. Geophys., 40(1), 1002, doi:10.1029/2000RG000095. 
1 Ramanathan, V., Crutzen, P. J., Lelieveld, J., Mitra A. P., Althausen D., Anderson J., 2 Andreae M. O., Cantrell W., Cass G. R., Chung C. E., Clarke A. D., Coakley J. A., 3 Collins W. D., Conant W. C., Dulac F., Heintzenberb J., Heymsfield A. J., Holben B., 4 Howell S., Hudson J., Jayaraman A., Kiehl J. T., Krishnamurti T. N., Lubin D., 5 McFarquhar G., Novakov T., Ogren J. A., Podgorny I. A., Prather K., Priestley K., 6 Prospero J. M., Quinn P. K., Rajeev K., Rasch P., Rupert S., Sadourny R., Satheesh S. K., 7 Shaw G. E., Sheridan P., Valero F. P. J., 2001. The Indian Ocean Experiment, An 8 integrated analysis of the climate forcing and effects of the Great Indo-Asian Haze. 9 Journal of Geophysical Research 106, 28371-28398. 13 areas determined by the Total Ozone Monitoring Spectrometer and surface observations, 14 Ann. Assoc. Am. Geogr., 93, 297-313. 


\section{Figure captions}

2

3 Figure - 1 (a-e) Variations of sky radiometer-derived AOD at different wavelengths (f)

4 Ångström exponent $(\alpha)$ (The symbols indicates mean and standard deviation.) during 52008.

Figure - 2 As in Fig.1, but for SSA.

Figure-3 Variation of SSA at different wavelengths in 2008.

Figure - 4 (a -b) Scatter plot of (a) Ångström exponent vs $\mathrm{SSA}_{500}$ and (b) BC vs SSA500.

Figure - 5 (a) True Color Composites of Terra MODIS and (b) Aqua MODIS on $2^{\text {nd }}$ February and $8^{\text {th }}$ March, 2008 showing intense dust aerosol loading over the Arabian Sea.

Figure - 6 NOAA HYSPLIT 5-day backward trajectories ending at Hyderabad, India on $2^{\text {nd }}$ February and $8^{\text {th }}$ March, 2008

Figure - 7 MODIS active fires composite showing increased occurrence of fires during Julian days $41-70$

Figure - 8 (a-f) Monthly average of aerosol volume size distribution during 2008.

Figure - 9 (a-d) Seasonal variations of aerosol volume size distribution during 2008.

Figure - 10 Scatter plot of Terra MODIS aerosol optical depth at $550 \mathrm{~nm}\left(\mathrm{AOD}_{550}\right)$ vs Sky radiometer $\mathrm{AOD}_{550}$. 

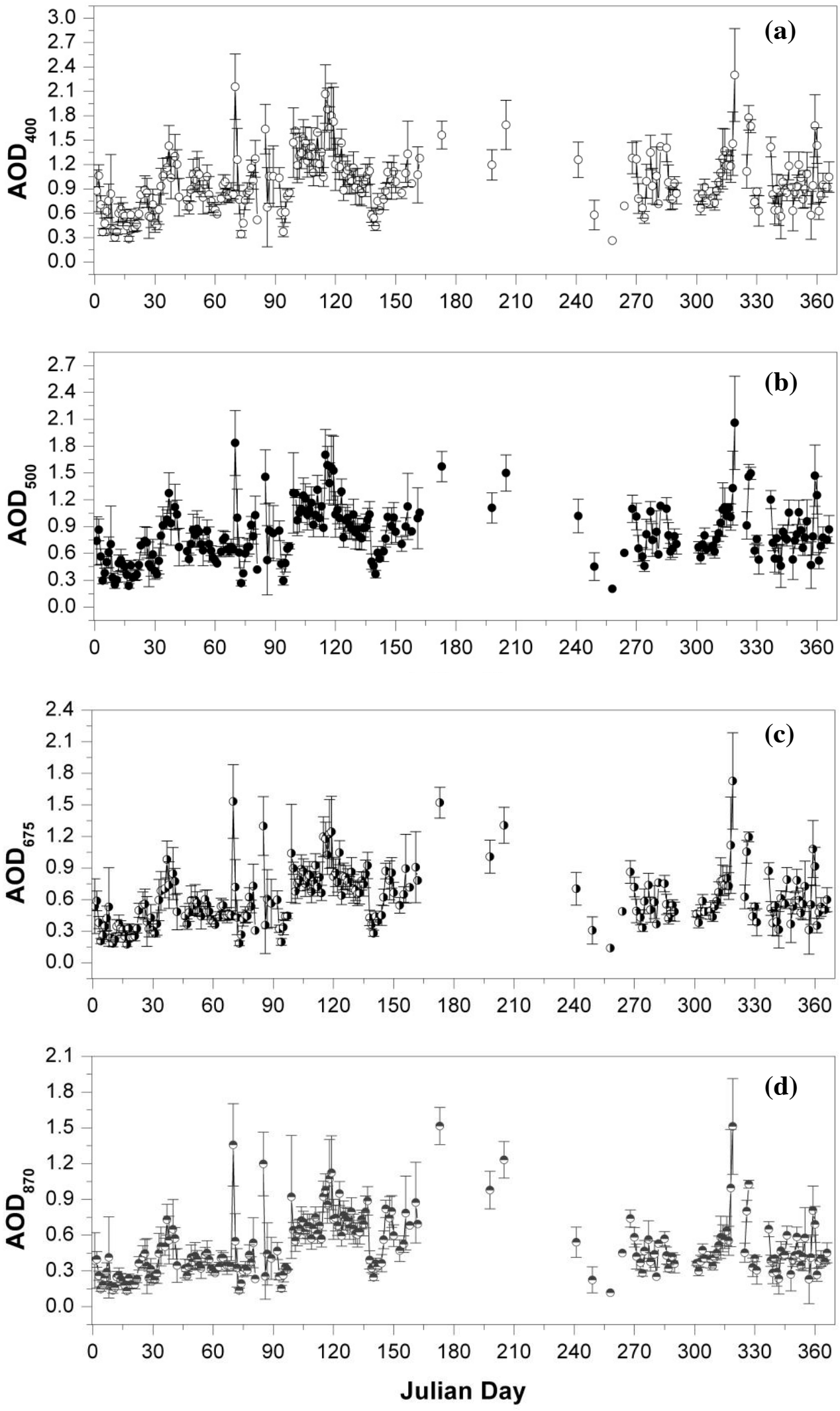

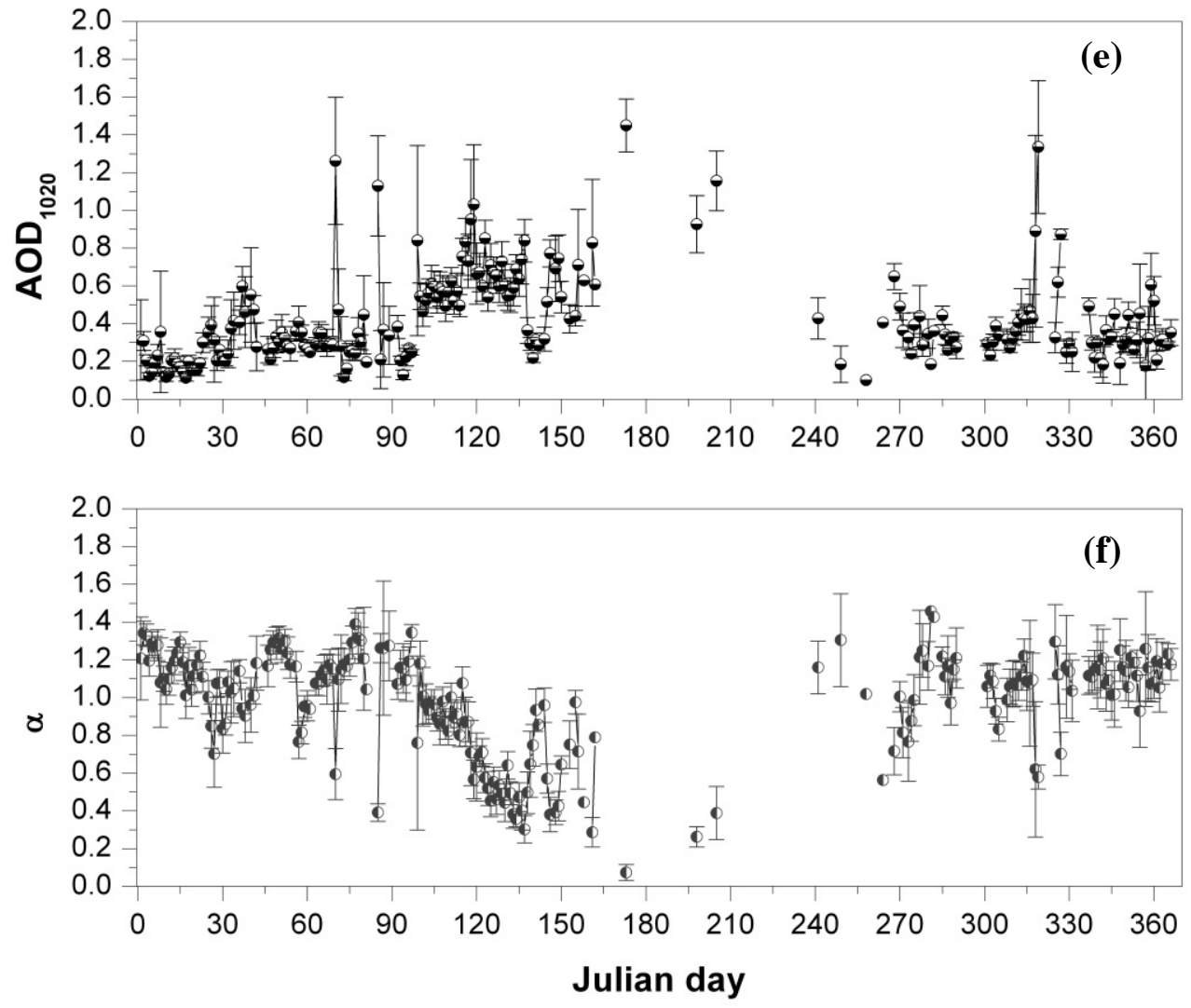

2 

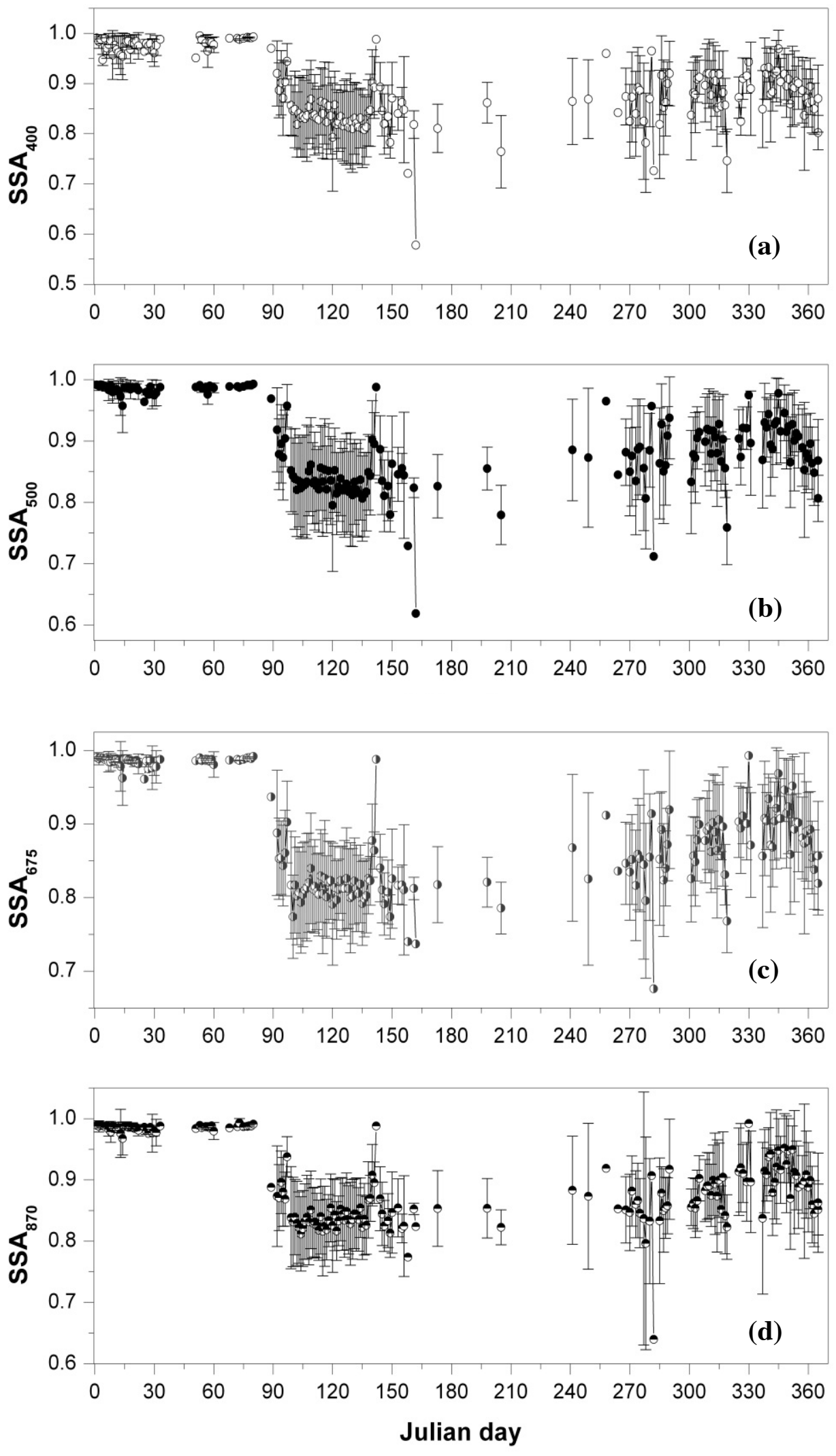


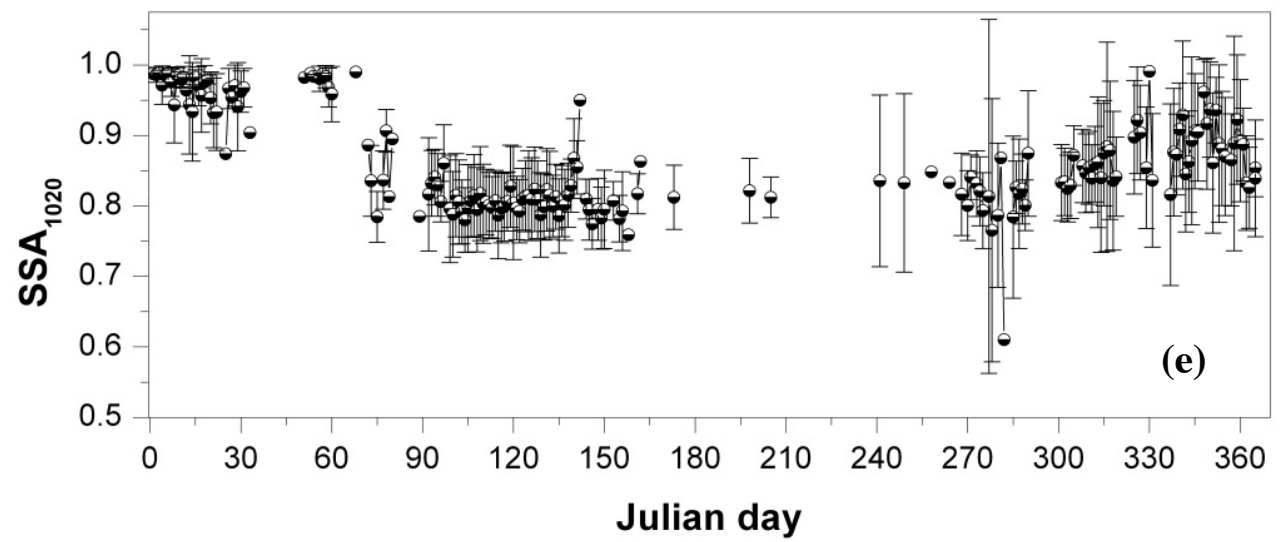

1

2

3 Figure -2

4

5

6

7

8 
1

2

3

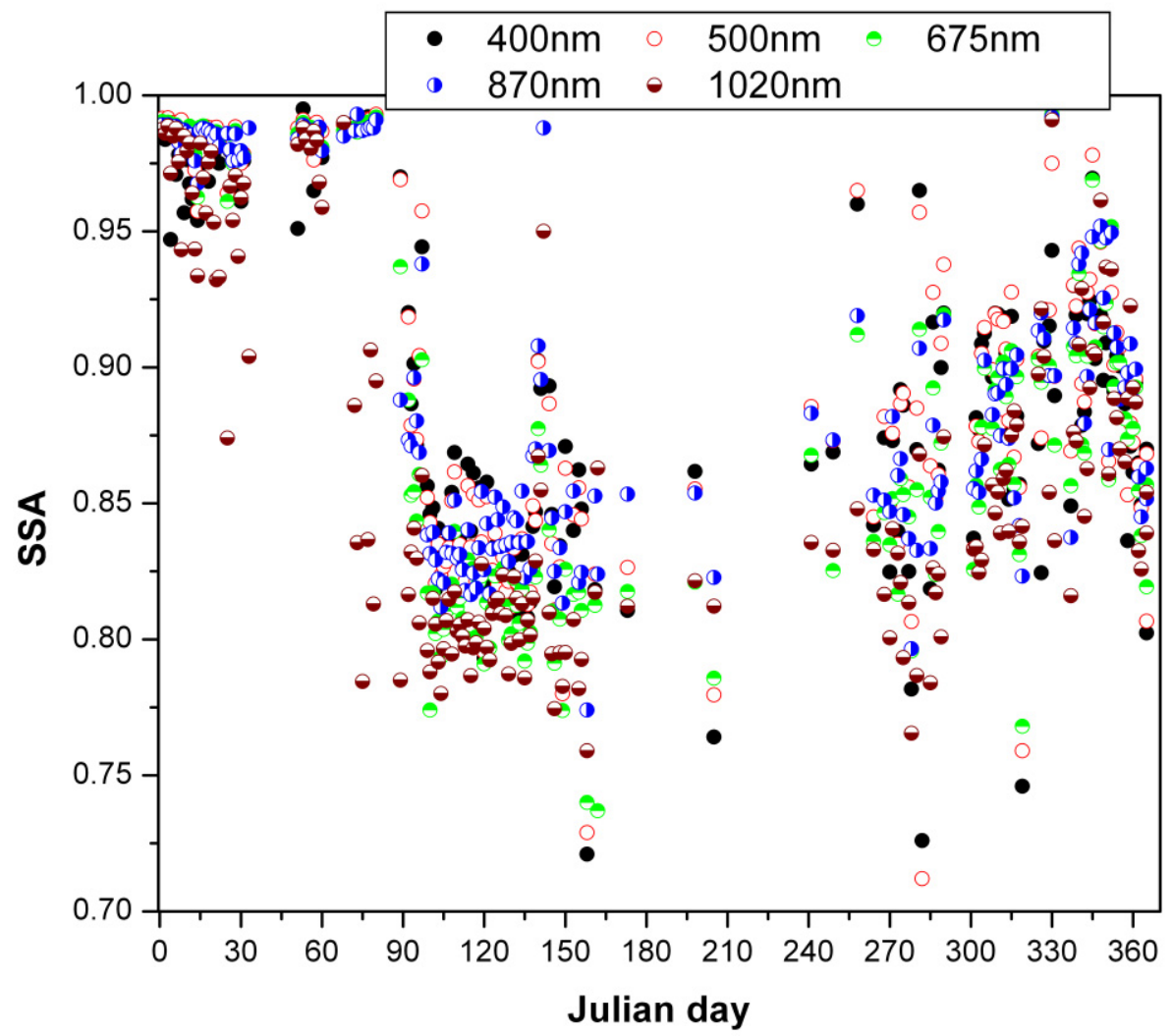

Figure-3 


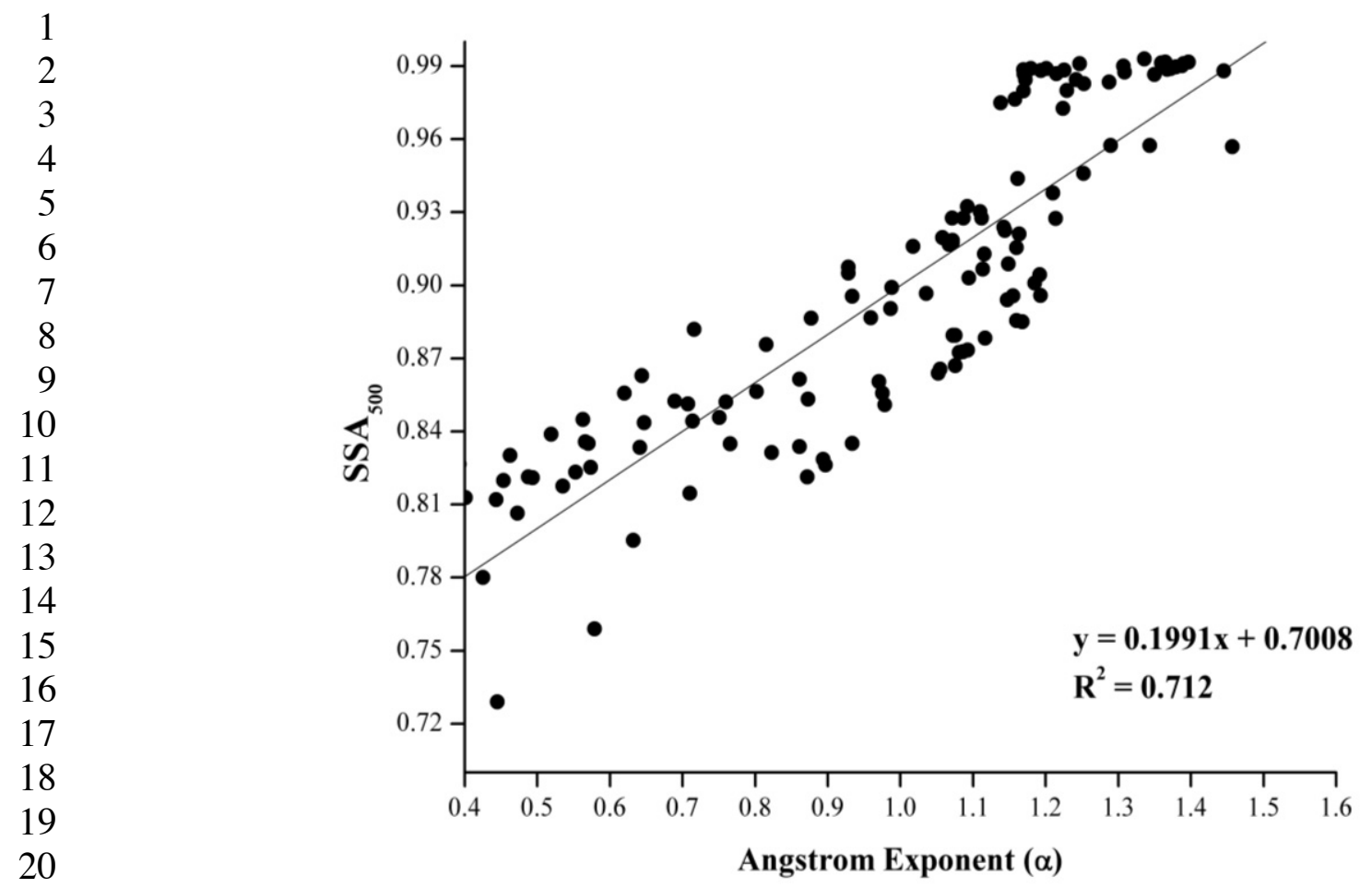

21

22

23

24

$45 \quad$ Figure 4

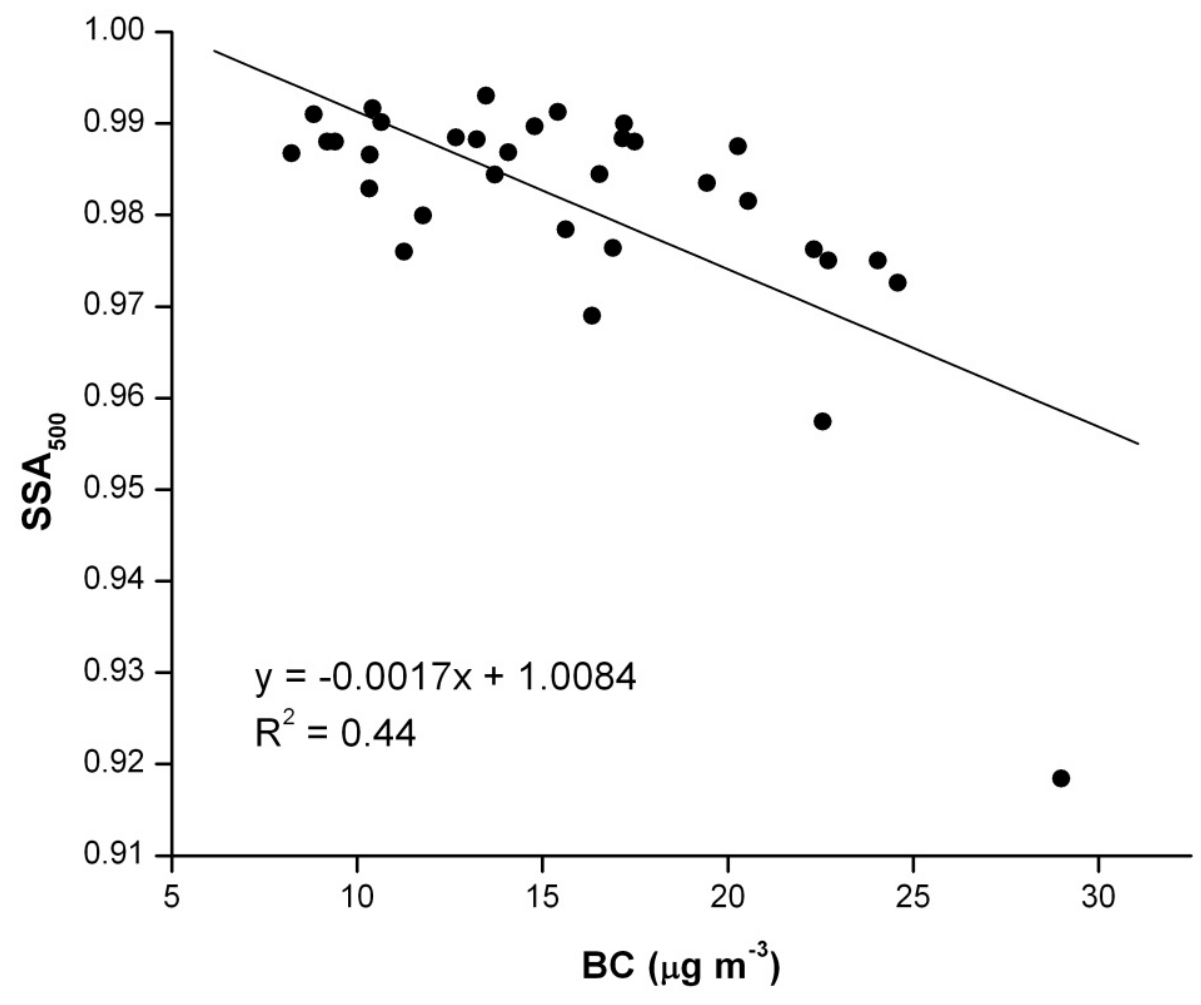



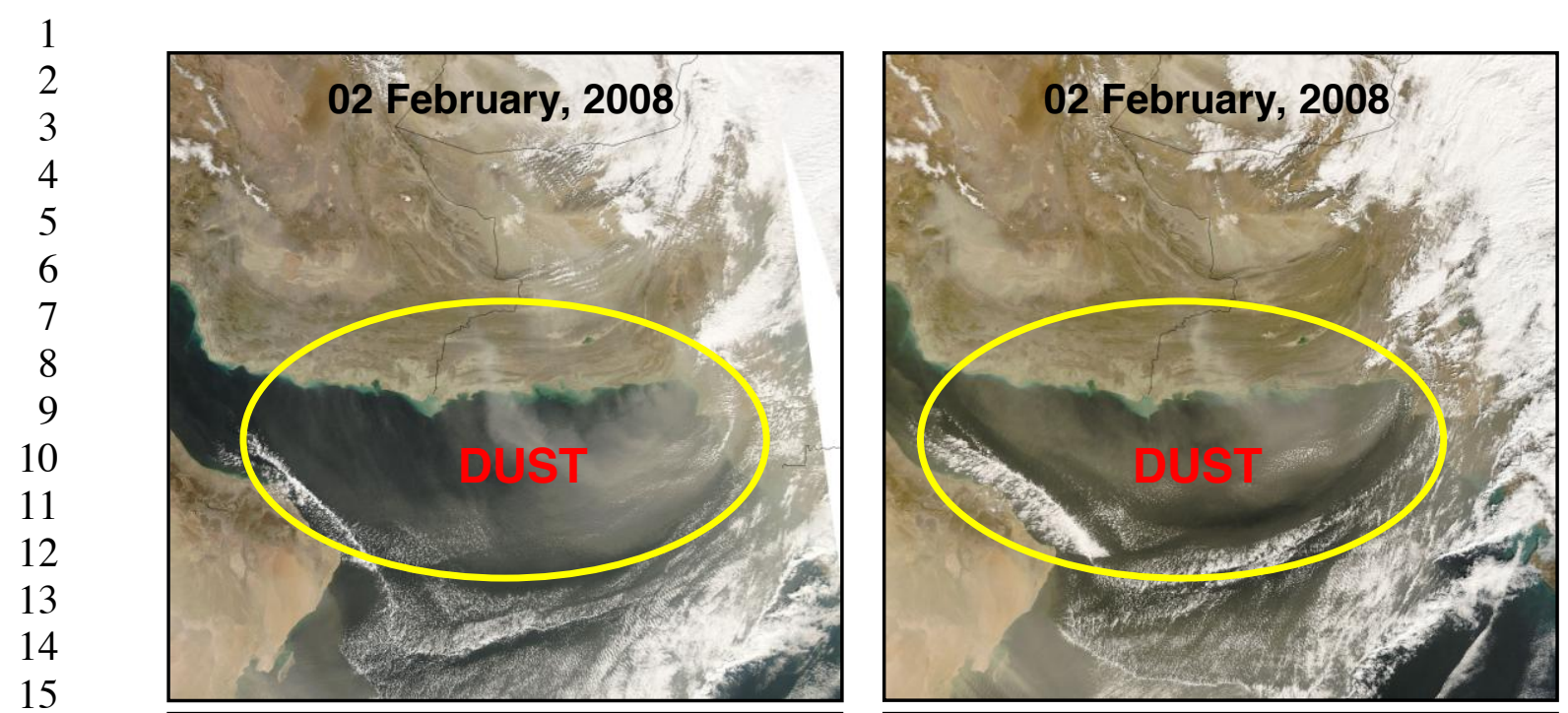

16

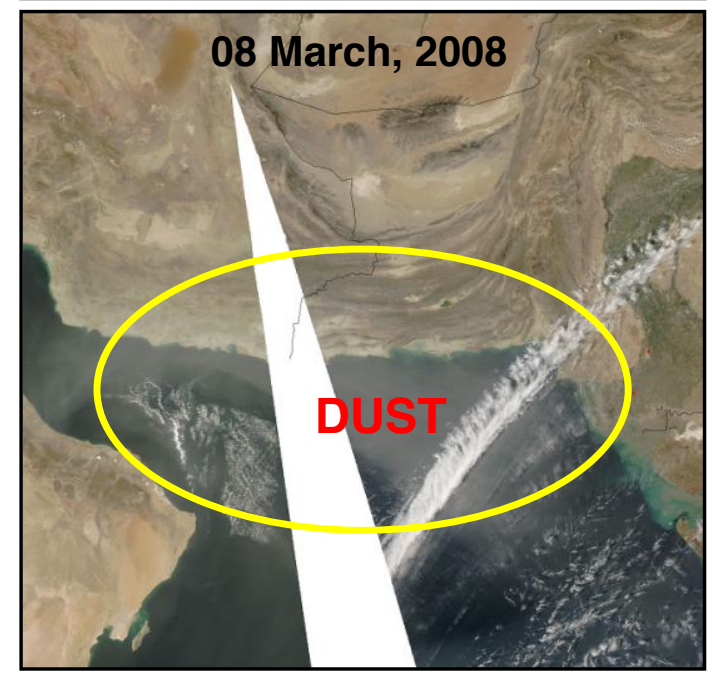

(a)

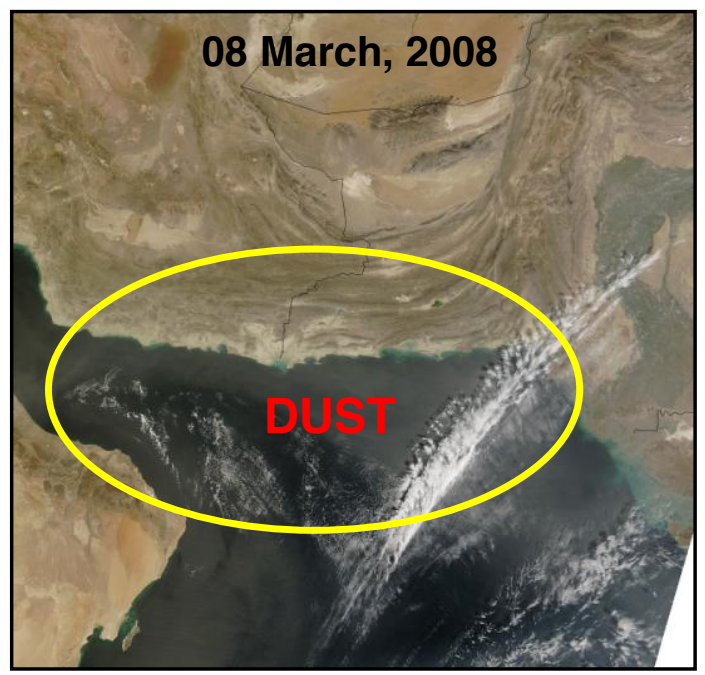

(b)

32

33

34 Figure - 5 
NOAA HYSPLIT MODEL

Backward trajectories ending at 00 UTC 02 Feb 08 GDAS Meteorological Data

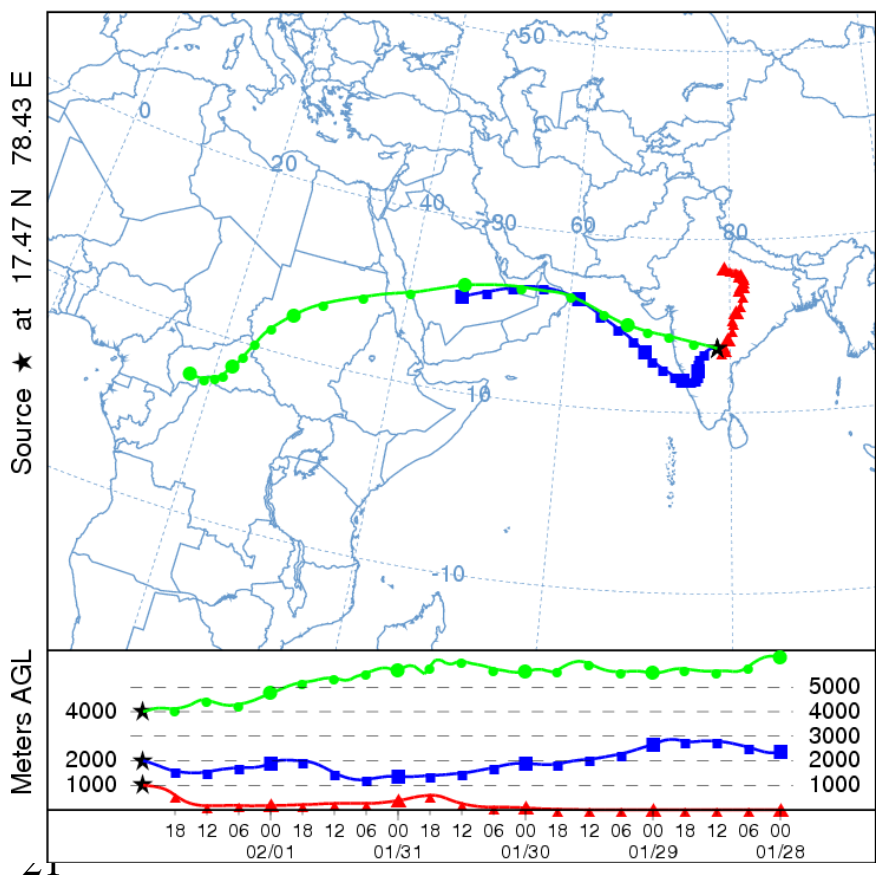

\section{2}

23

24

25

26
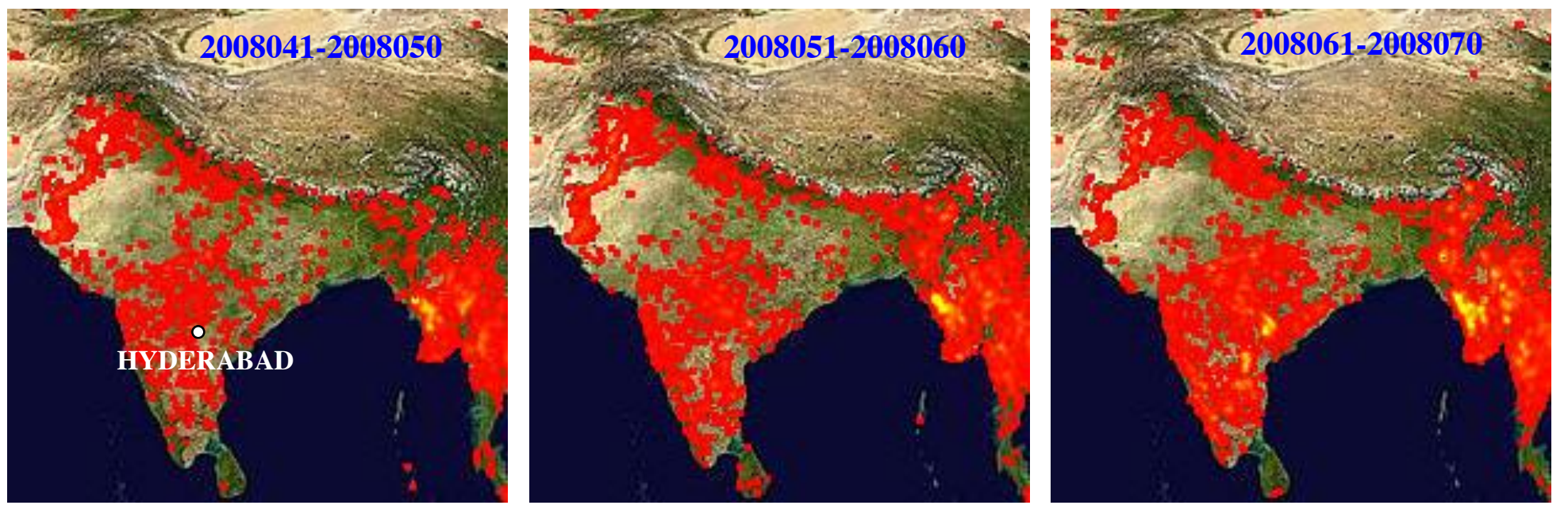

$28 \quad$ Figure -7

29

30

31

32

33 

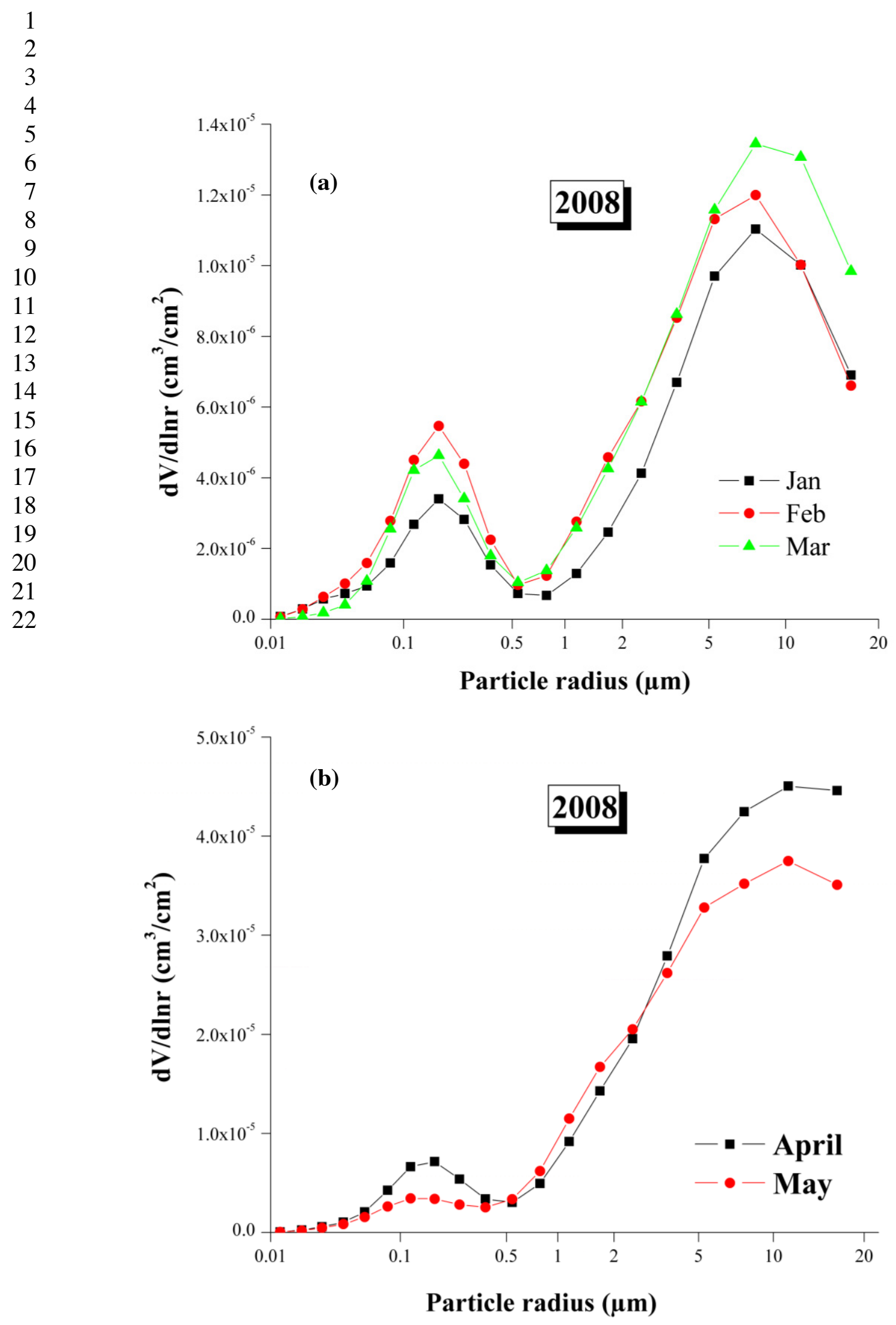


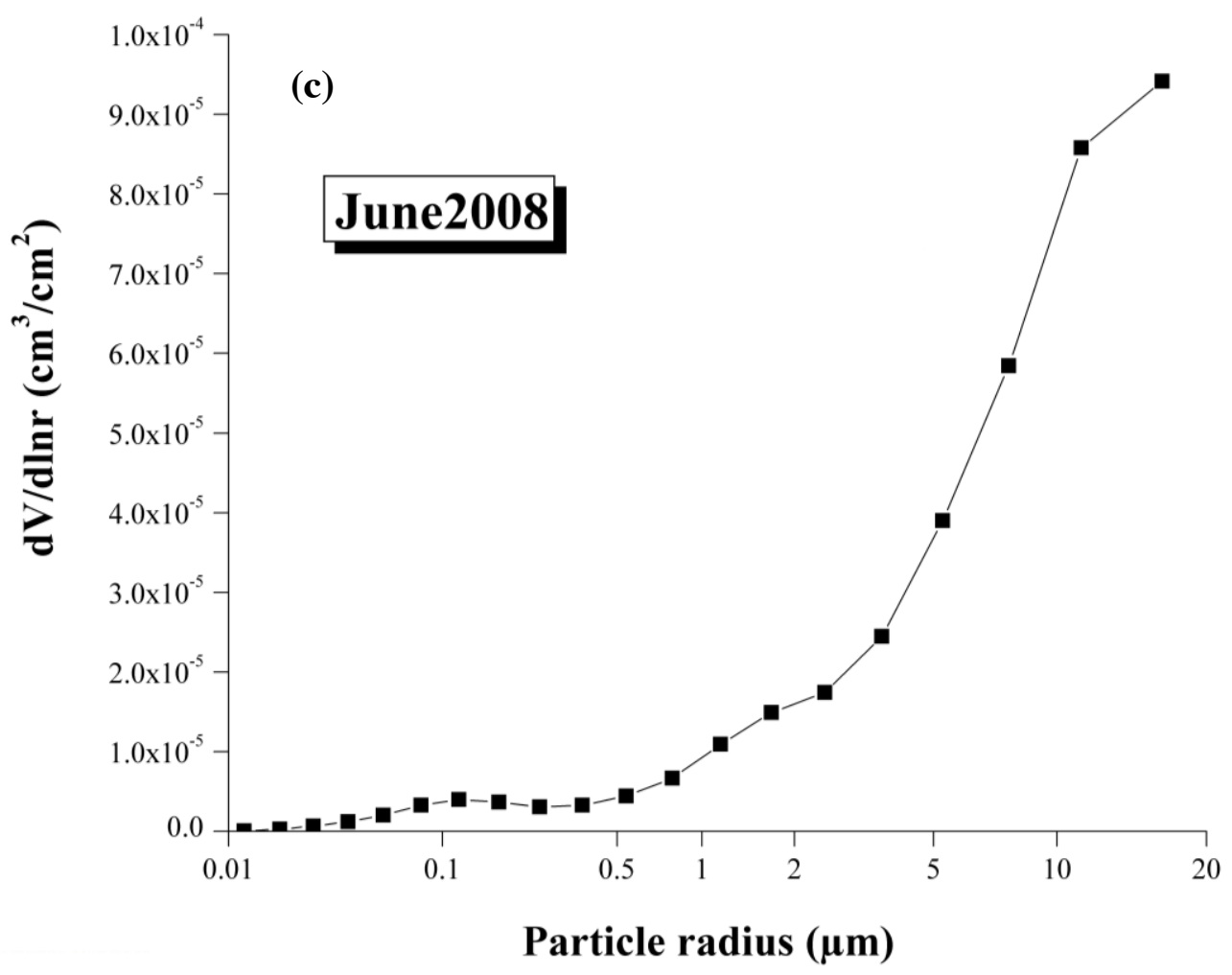

21

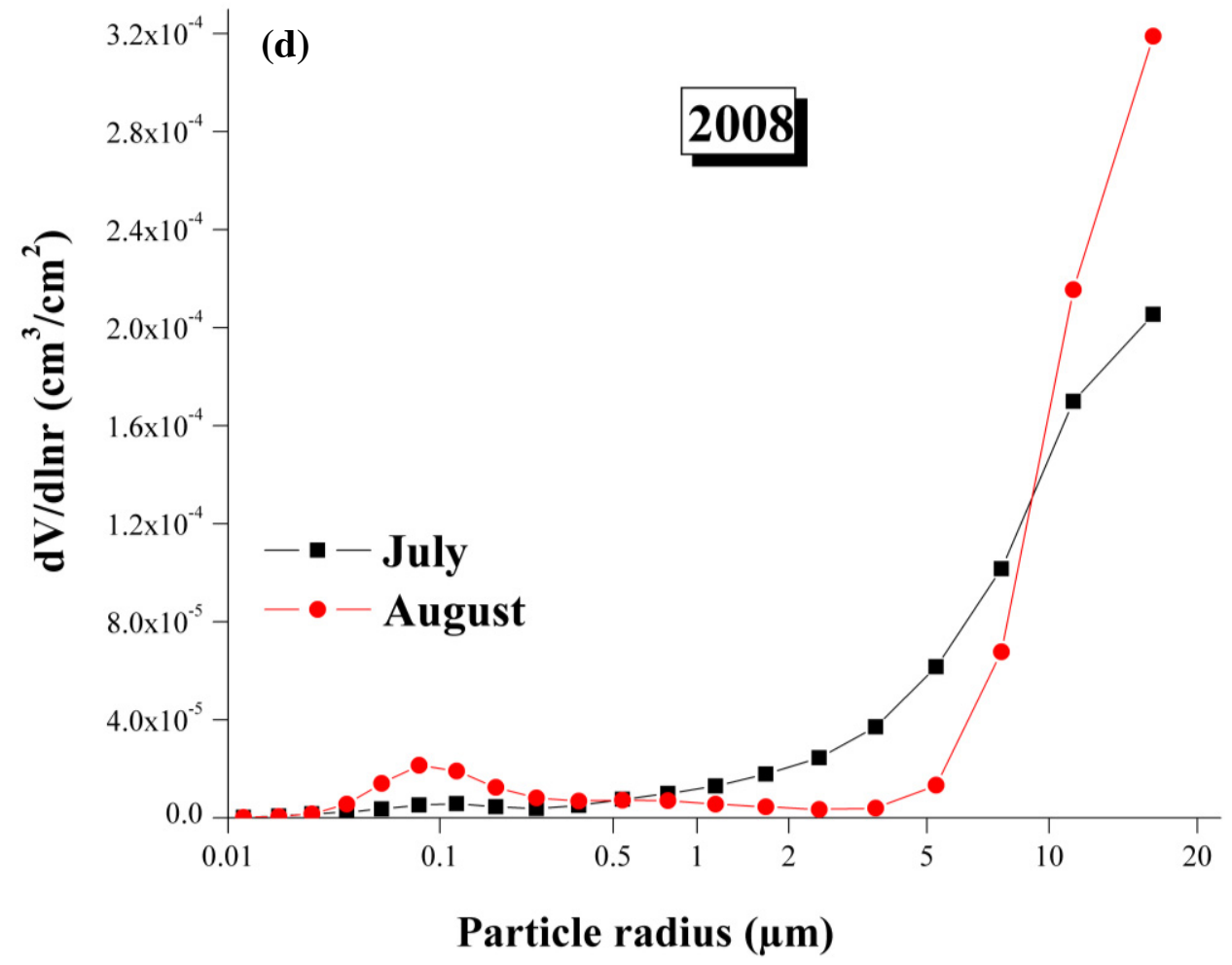




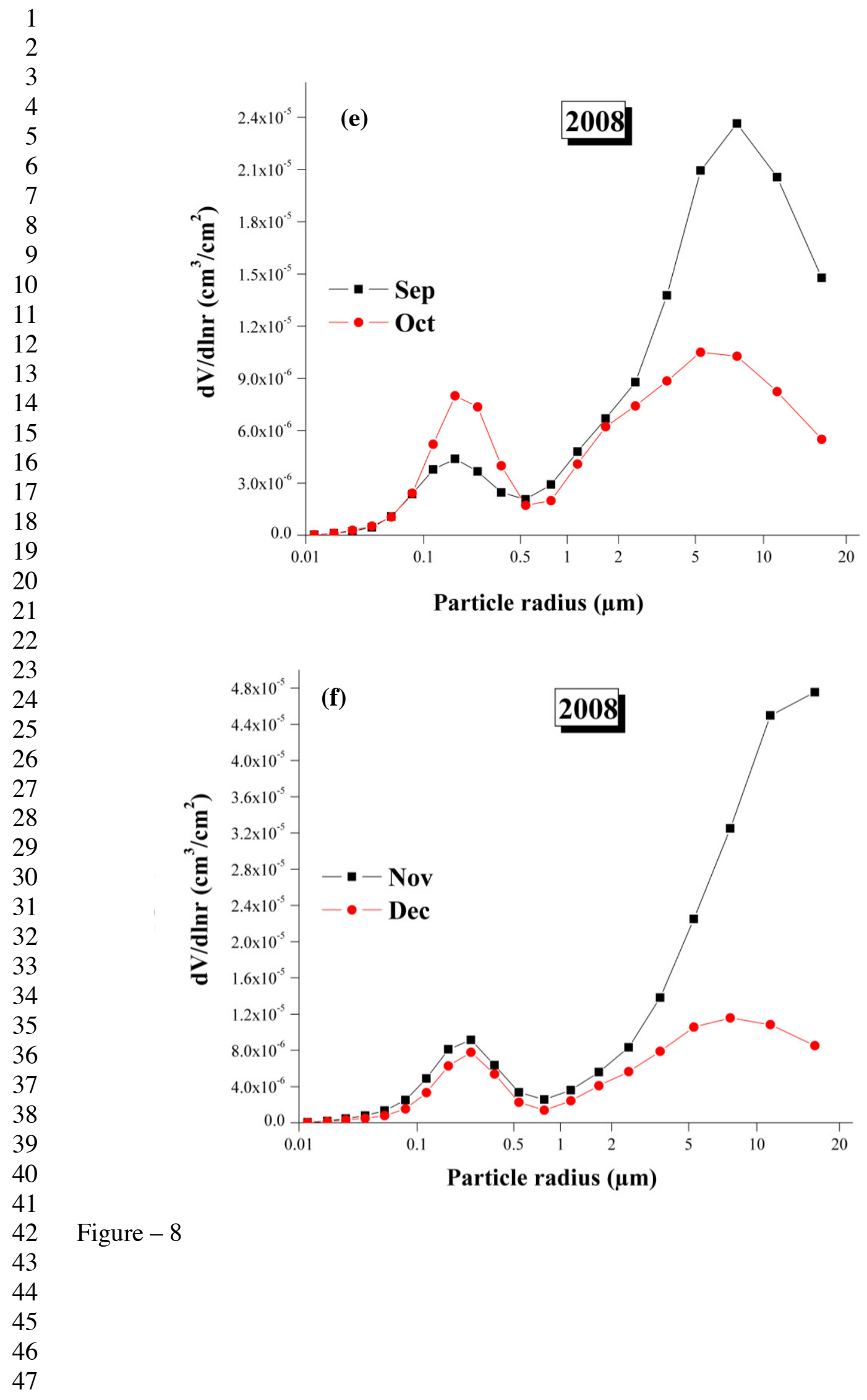



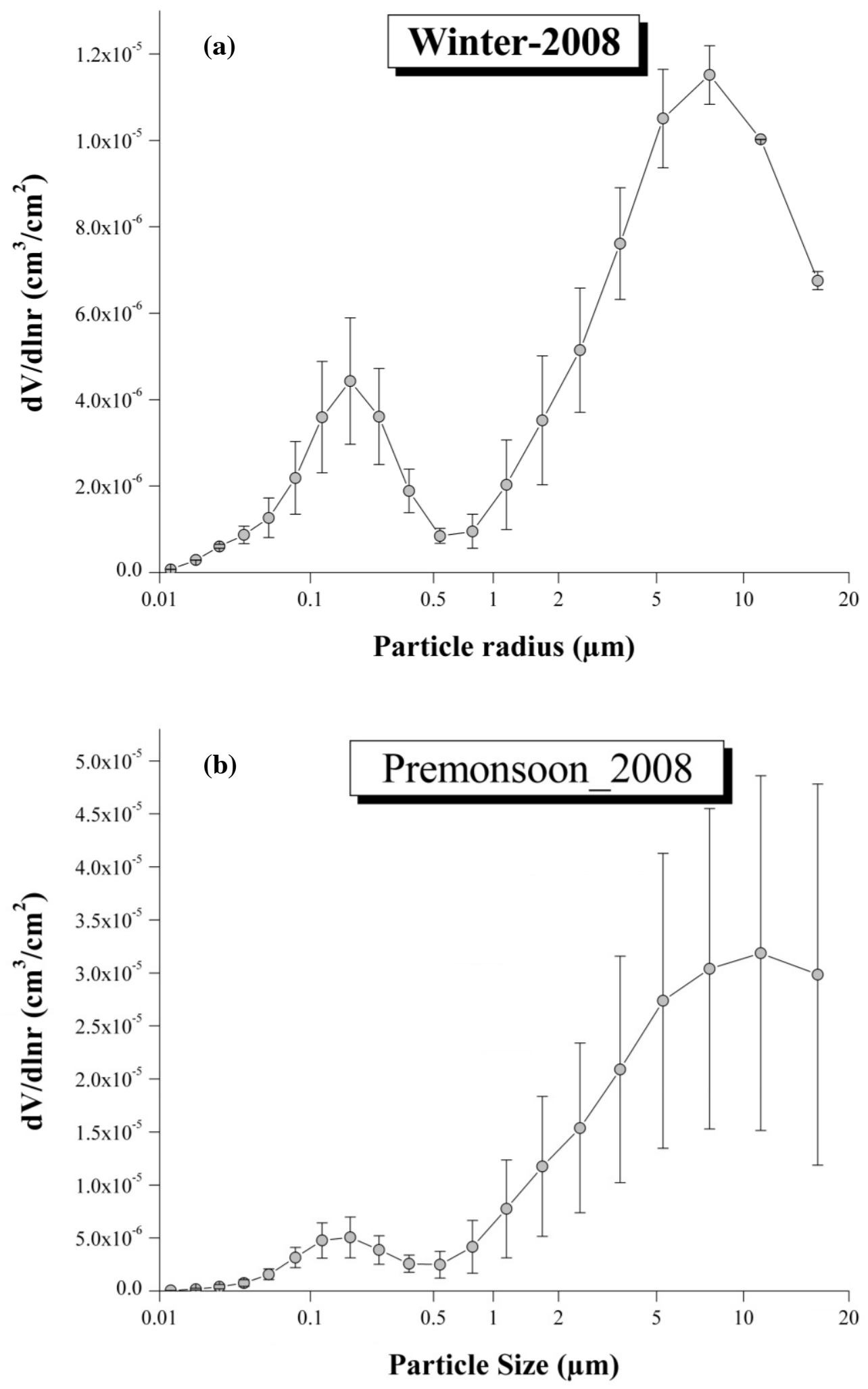


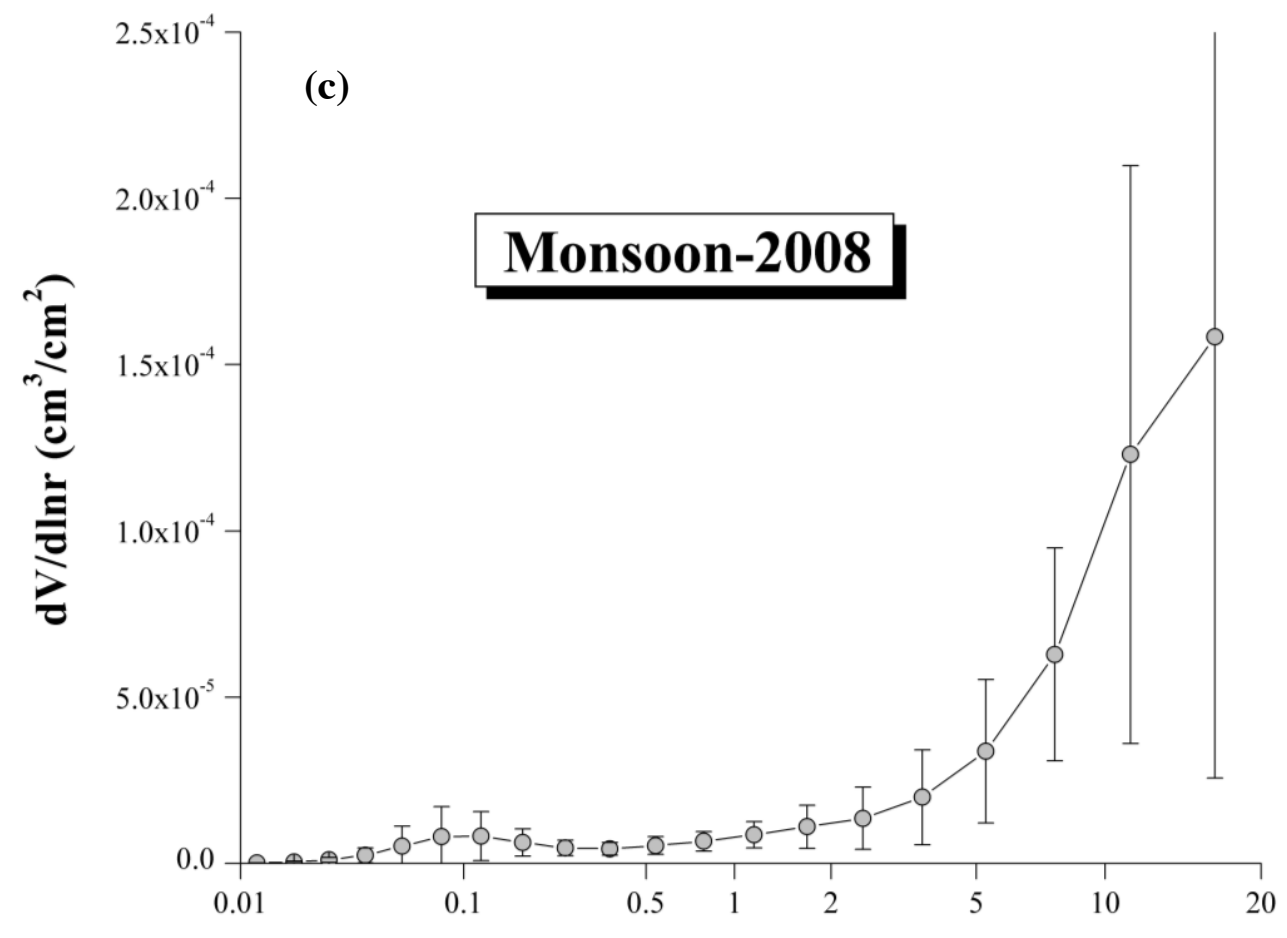

Particle Size ( $\mu \mathrm{m})$

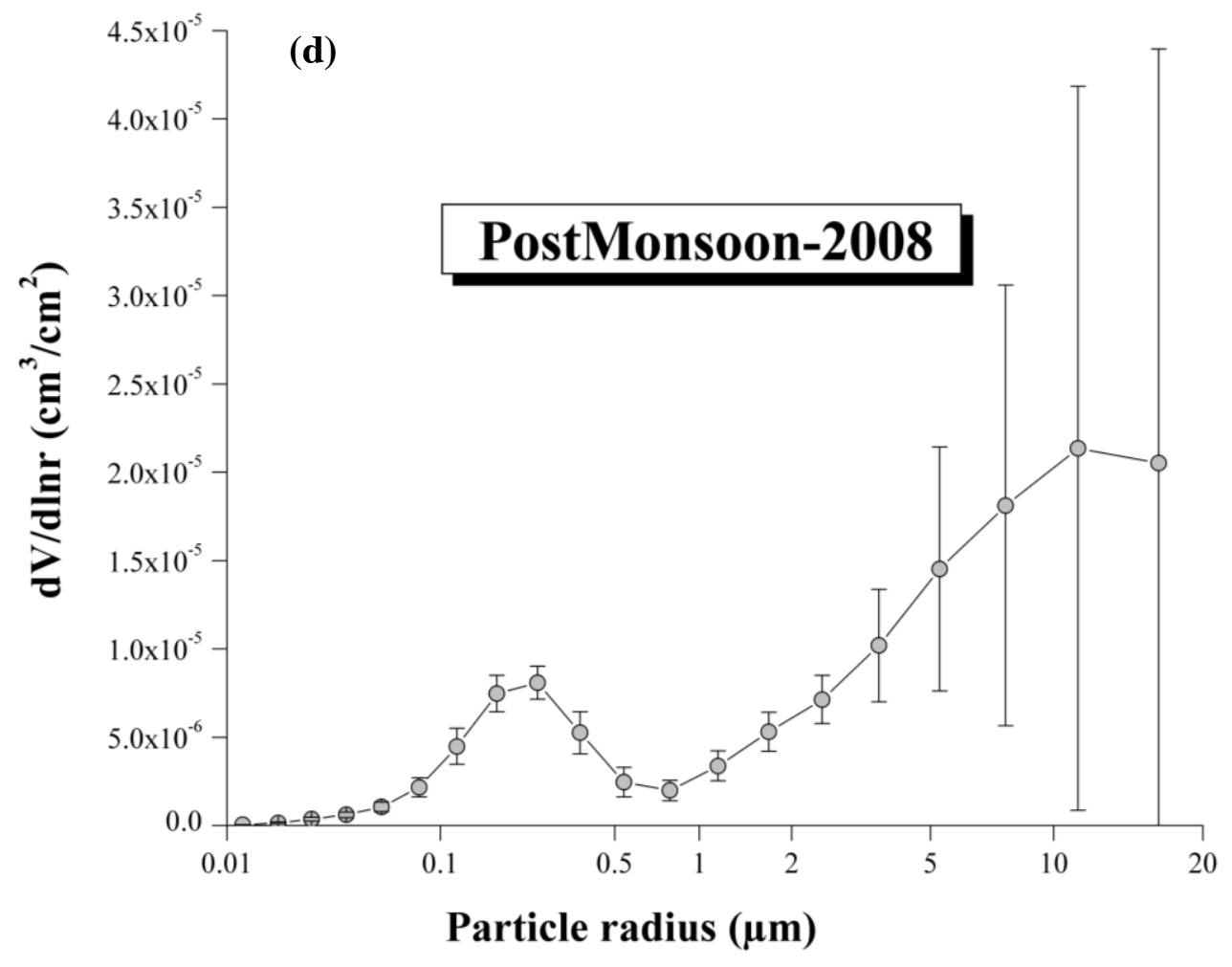

31 Figure - 9 
29

30

31

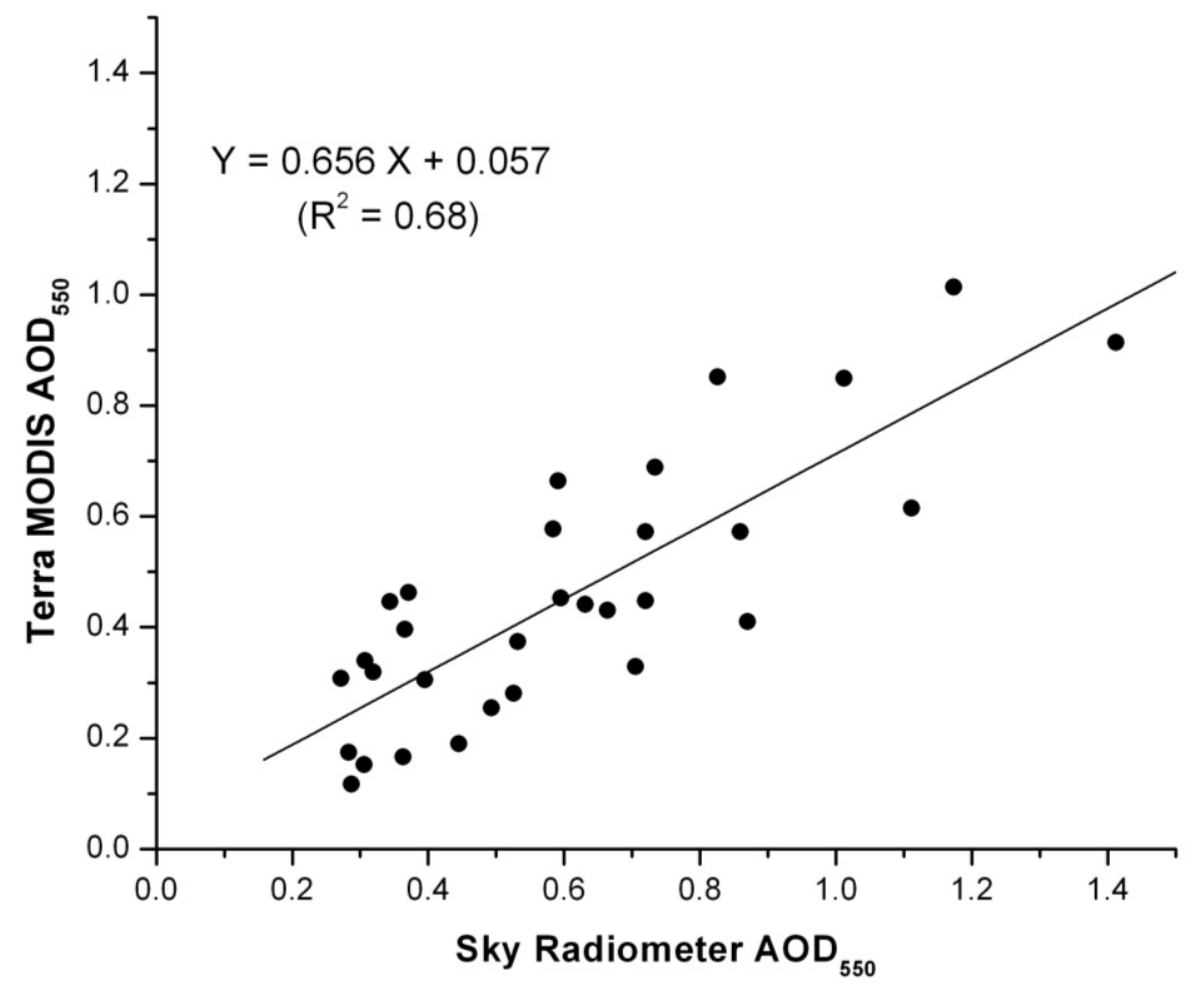

Figure - 10 